Hakan Yalap

University of Nevşehir

Hacı Bektaş Veli

hakanyalap@hotmail.com

https://doi.org/10.18485/ai_san_o_gradu.2019.ch15

726:75.046.3(560)

\title{
GOREME OPEN AIR MUSEUM
}

Goreme Open Air Museum is one of the most special formations of Cappadocia. The region has been a UNESCO World Heritage Site since 1985, as a natural and cultural entity. Göreme Open Air Museum, $2 \mathrm{~km}$. The site is a rock settlement area to the south. MS. From the 4 th century to the 13 th century, a busy monastic life was experienced.

In the initial parts of the valleys in the Cappadocia region, large rock blocks are usually formed as a result of natural erosion. The Göreme Open Air Museum was established in the immediate vicinity of such a valley and almost every rock block in the surrounding area was carved and used for various purposes.

The museum consists of monasteries, churches, chapels, dining halls, kitchens and living spaces carved into the rock. The monastery education system was launched in Göreme Open Air Museum. Soğanlı, Ihlara, Açıksaray's education system is seen later. The churches are painted with 2 types of techniques. First, it was made by correcting and correcting; secondly, it is made with the use of secco (tempera) and fresco technique on rock. Topics covered in the Bible and the Prophet. Sections of Jesus' life. Goreme Open Air Museum includes the Monastery of Girls and Boys, St. Basil's Church, Elmalı Church, St. Barbara Church, Yılanlı Church, Karanlık Church, Çarıklı Church and Tokalı Church.

This region was founded by St. Basil, the bishop of Kayseri, an important person in the history of Christianity. The ideas of St. Basil, who brought a lot of innovation to Christian thought, were first taught here. The monastic life 
in the region lasted for 1000 years. Cappadocia is surrounded by churches carved into the rocks all around, and there are around 360 carved churches. The Göreme Open Air Museum, which contains the best preserved Byzantine churches and frescoes, is the crown of the region.

Key words: Goreme Open Air Museum, Cappadocia, Turkey, Christianity

Goreme town $2 \mathrm{~km}$. is a rock settlement located to the east. A.D. From the 4th century until the 13th century, the monastery life was intensely lived. Almost every rock block has churches, chapels, dining halls and living spaces. Göreme Open Air Museum is considered to be the place where the monastic education system was started. Soğanl, Ihlara, Açıksaray are the places where the same education system was seen later. Churches are painted with two types of techniques. First, painting on the surface by correcting the rock directly; The second one is the staining with the secco (tempera) and fresco technique on the rock. Topics covered in the Bible and the Prophet. It was taken from the life of Jesus. Goreme Open Air Museum includes the Monastery of Girls and Boys, St. Basil's Church, Elmalı Church, St. Barbara Church, Yilanlı Church, Karanlik Church, Çarıklı Church and Tokalı Church.

The Göreme Open Air Museum has been a UNESCO World Heritage Site since 6 December 1985 as a natural and cultural asset.

The ideas of St. Basil, who brought many innovations to Christianity, were first taught here and the monastic life in the region lasted for about a thousand years.

This first building is located at the entrance of the museum. In other words, it is the place where female students are educated. It is a 7-storey complex with a dining room, kitchen, chapel and church. The floors are connected to 
each other by tunnels.

There is a monastery of the monks. That is the school of male students. The monastery of the monks is also multi-storey, like the monastery of the nuns.

In the initial parts of the valleys in the Cappadocia region, there are generally large rock-block formations. This is a result of natural etching. The Göreme Open Air Museum was also established in the immediate vicinity of such a valley. Almost every rock block in the surrounding area has been carved and used for various purposes. After transforming the region into a museum, landscaping was made suitable for the tour.

\section{Churches in Göreme Open Air Museum: Monastery of the Priests and Nuns:}

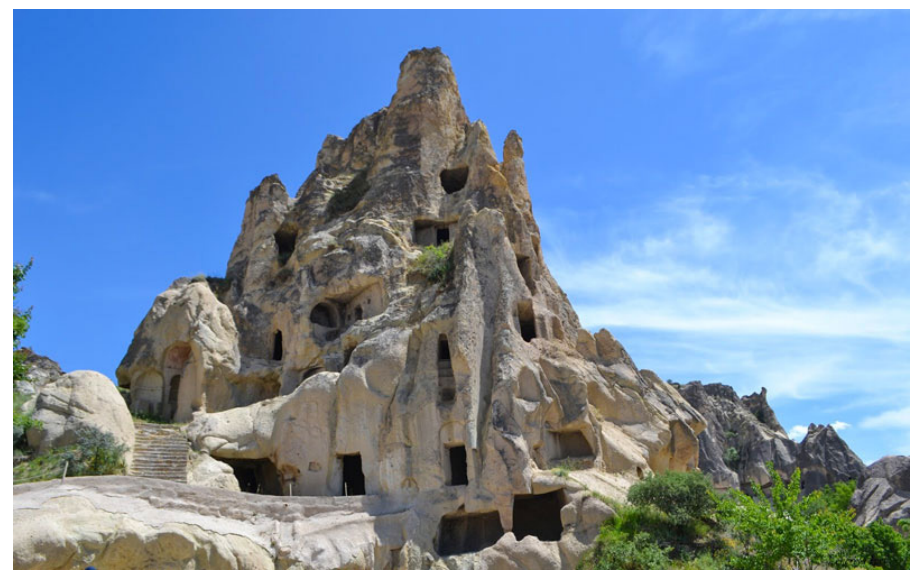

The 6-7 storey rock mass located to the left of the museum entrance is known as the "monastery of the nuns". The cafeteria on the 1st floor of this monastery has a few rooms; The ruined chapel on the 2 nd floor is viewable. The church on the 3rd floor (reached by a tunnel) has three domes with 
four domes and a cross-dome. The templona in the main apse is uncommon in other churches in Göreme. In the church, there is a red ornament on the rock. The connection between the floors in the monastery was provided by tunnels. "Sliding stones" were used in underground cities to close the tunnels in case of danger. The monastery on the right can only see several rooms on the ground floor, as the passage between the floors is closed due to erosion.

\section{Chapel of St. Basil:}

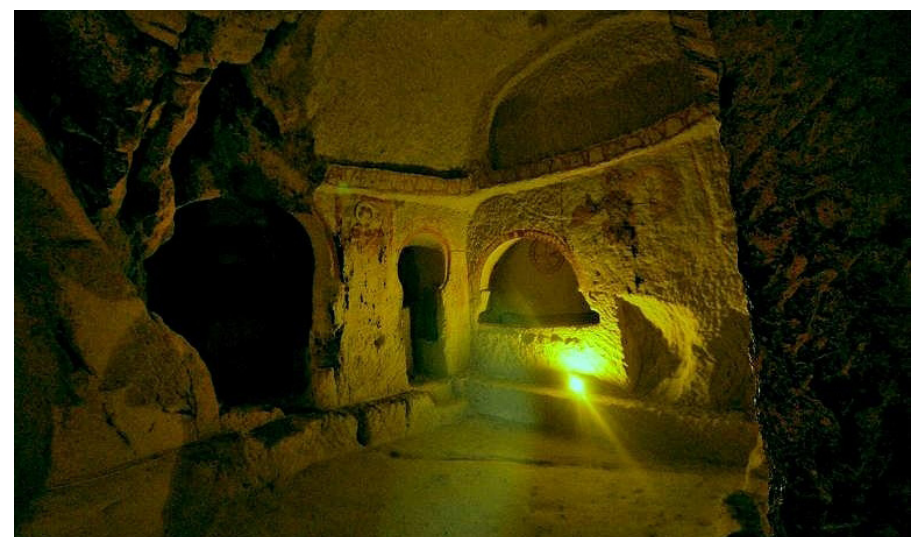

It is at the entrance of Göreme Open Air Museum. There are burial pits in the narthex separated by columns. The nave has a transverse barrel vault, a rectangular plan and three apses. On the left side of the rectangular nave is one big, two small, three abscesses. The church dates back to the 11 th century.

The scenes in the church are: the portrait of Jesus in the main apse, the Virgin Mary and the child Jesus on the front, St. Theodore on the horse in the north wall, the depiction of Saint George fighting the dragon on the horse in the south wall, the portrait of Saint Demetrius and the two saints. 


\section{Elmali Church:}

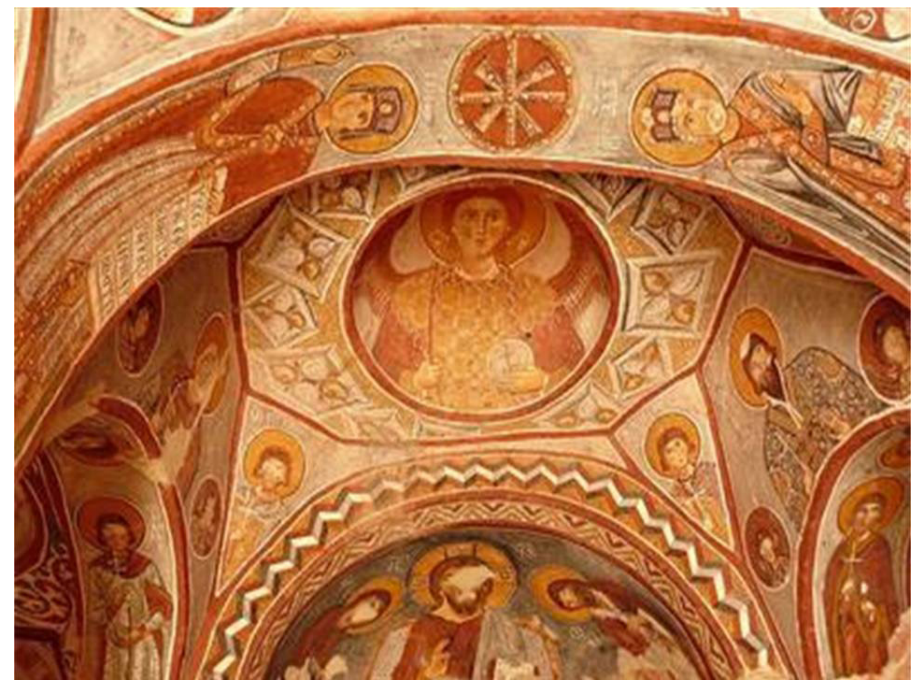

It has nine domes, four columns, closed Greek crosses and three apses. The main entrance to the church from the south direction can be entered through a tunnel opening from the north. The first decorations of Elmalı Church are the cross and geometric motifs made with red paint on the wall as in the Basilica of Saint Basil and Saint Barbara. The church dates from the middle of the 11th century to the beginning of the 12th century. 


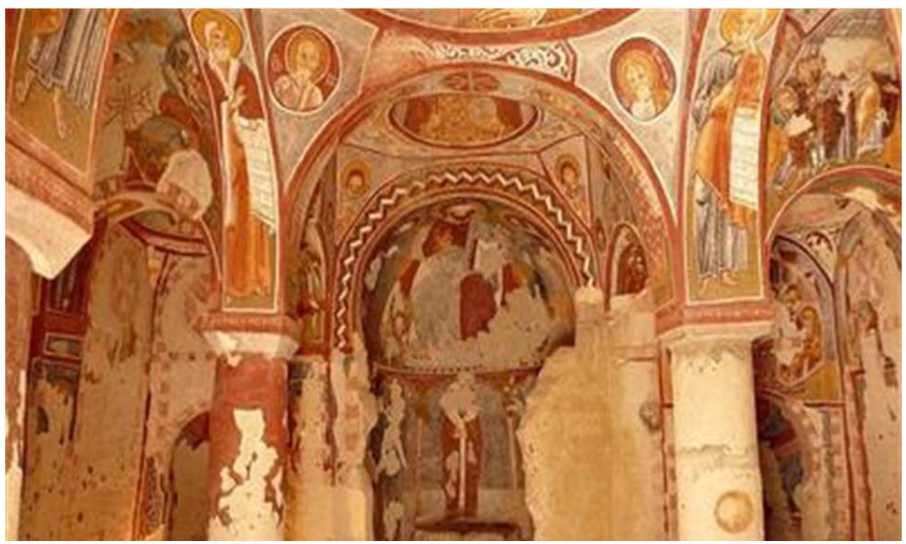

Scenes in the church: Deesis, birth, worship of three astrologers, baptism, resurrection of Lazarus, metamorphosis, entry to Jerusalem, last supper, betrayal, Jesus on the way to Golgotha, Jesus on the cross, Jesus' burial, Christ to hell, women at the beginning of the empty tomb, depicting Jesus ascension and saints. In addition, the hospitality of Abraham prophet from the Torah and the burning of three Jewish youths in the oven is depicted.

\section{Saint Barbara Chapel:}

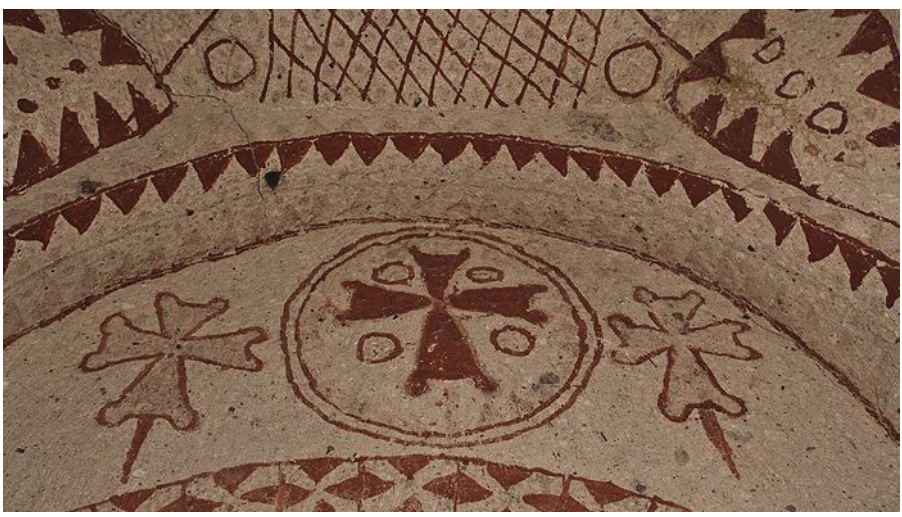


It is behind the rock block where Elmalı Church is located. Cross-shaped, two-column, west, north and south cross arms, barrel vaulted, central dome, eastern cross arms and two corner corners are dome in the east. There are two main apses, one main.

The motifs are drawn directly on the rock with red paint. There are rich geometric motifs, mythological animals and military symbols on the walls and dome. There are also motifs on the walls. The church is dated to the second half of the 11th century.

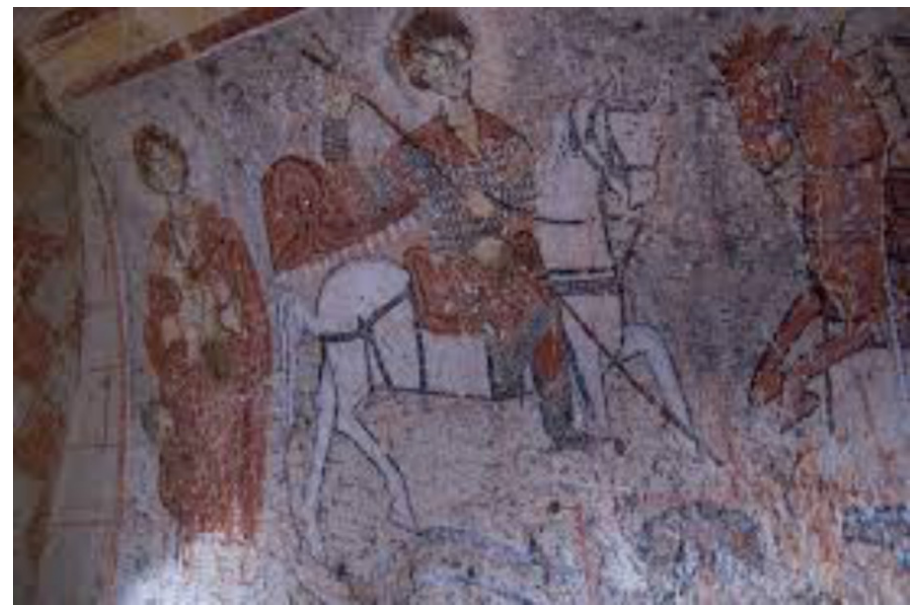

Scenes in the Church: Jesus pantokrator in the main apse; Saint George and St. Theodore who fought with the dragon on the arm of the northern cross; in the western cross arm is the depiction of St. Barbara. 


\section{Yılanlı (Aziz Onuphrius) Church:}

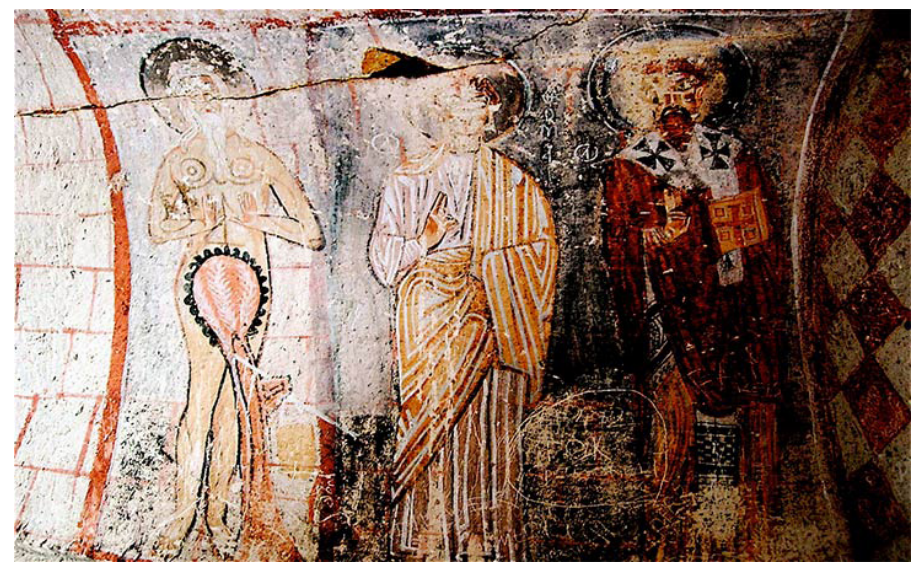

The entrance to the church is north. The main space is a rectangular rectangular plan, barrel vaulted, and the tombs in the south have a flat roof. The apse was carved into the left long wall, the church was left uncompleted.

There are depictions of saints in Cappadocia on both sides of the church vault. The church dates back to the 11th century.

Scenes in the Church: Jesus holding the bible in the left hand against the entrance, and the church's one next to him, Aziz Onesimus to the east of the vault, St. George and St. Theodore who fought the dragon, Helena and his son Constantine holding the true cross; west of the vault is St. Onuphrius with naked, long hair and a palm tree in front of him. St. Thomas is in the sanctity position and St. Basil with a book in his hand.

In the 1st century $\mathrm{AD}$, in the deserts of Egypt, people living in the secluded area called adi hermit $d$ lived in seclusion. The last hermit to learn the life and life styles of St. Paphnutius hermit m.s. He went to the deserts of Egypt in 
the 4th century and met with St. Onuphrius, who gave his name to the church. St. Paphnutius helped St. Onuphrius die. Because he was the best example of virtue, dominance of the nuke. In the depictions of Aziz Onuphrius, naked, long hair, large structure, palm tree stands in front.

Cellar, kitchen, dining room are side by side and connected with each other. In the first space used as pantry, there are cavities for storing supplies. In the kitchen, there is a stove called yler tandir $t$ which is still used in the local villages. The last part is the dining hall. On the left side of the entrance there are stone tables and tables where 40-50 people can eat. On the right side of the table there is a must to crush grapes.

\section{Karanlık Church:}

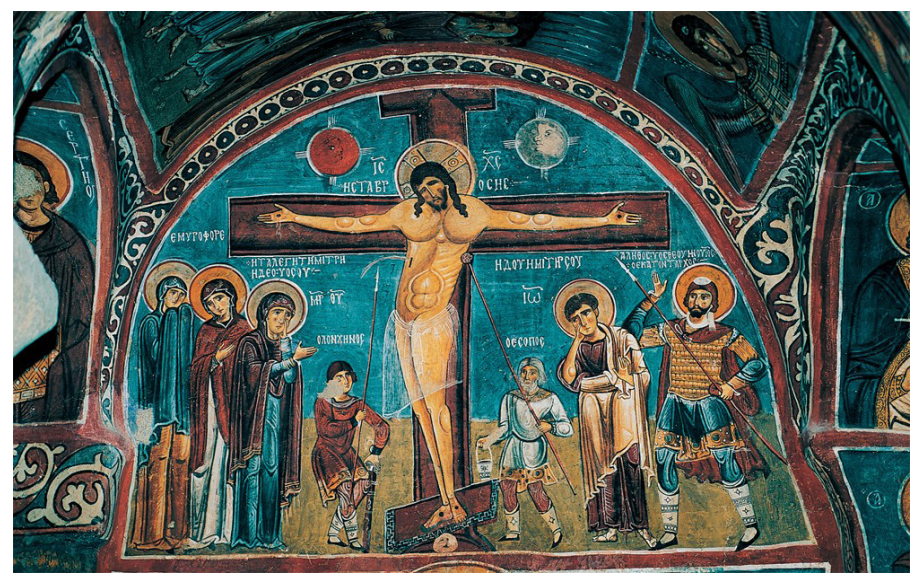

The dark church, a curved staircase in the north leads to the rectangular, barrel vaulted narthex of the church. There is a grave to the south of the narthex. The church has a cross-vaulted central dome, four columns and three apses. 
The reason why it is called the Dark Church is that it receives very little light from a small window in the narthex section. Therefore, the colors in the frescoes are quite vivid.

The church and the narthex have rich decorations including the Bible and the Jesus cycle. In addition, as in Elmalı and Çarıklı Church, scenes from the Torah are also depicted. The church is dated to the end of the 11th century and the beginning of the 12th century.

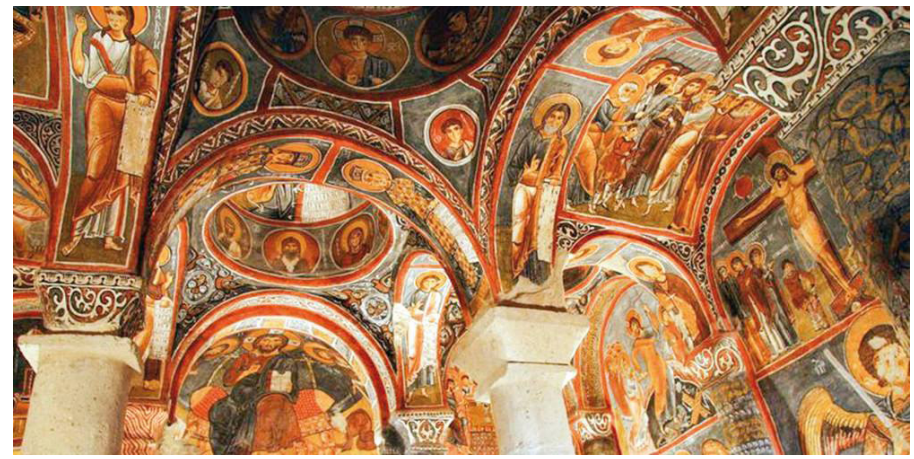

Scenes in the church: Deesis, gospel, Journey to Bethlehem, birth, worship of the three astrologers, baptism, Lazarus revival, metamorphism, Jerusalem entry, last supper, betrayal, Jesus on the cross, Christ landing in hell, women empty tomb at the beginning, the promotion and assignment of the apostles, the ascension of Jesus to heaven, the hospitality of the Prophet Abraham, the burning of three Jewish youth, and depictions of saints. 


\section{Çarıklı Church:}

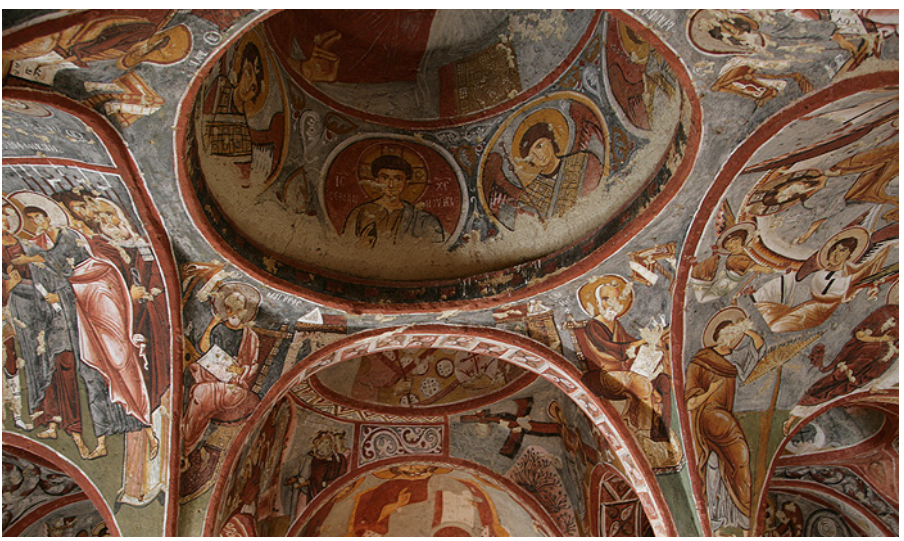

Because of the footprints of Jesus under the ascension scene, it is thought that the church was called dolay the church which is a reminder İsa. The church is dated to the end of the 12th century and the beginning of the 13th century.

In the middle of the main dome are pantokrator Christ, medallions of angel busts. In addition, the main apse deesis, the northern apse Mary and the child Jesus, the southern apse is the depiction of the angels Michael.

The scenes in the church are: Birth, worship of three astrologers, baptism, the resurrection of the Lazarus, the metamorphosis, the entrance to Jerusalem, betrayal, women at the empty grave, Jesus' ascension to the sky, and depictions of the saints. 


\section{Tokalı Church:}

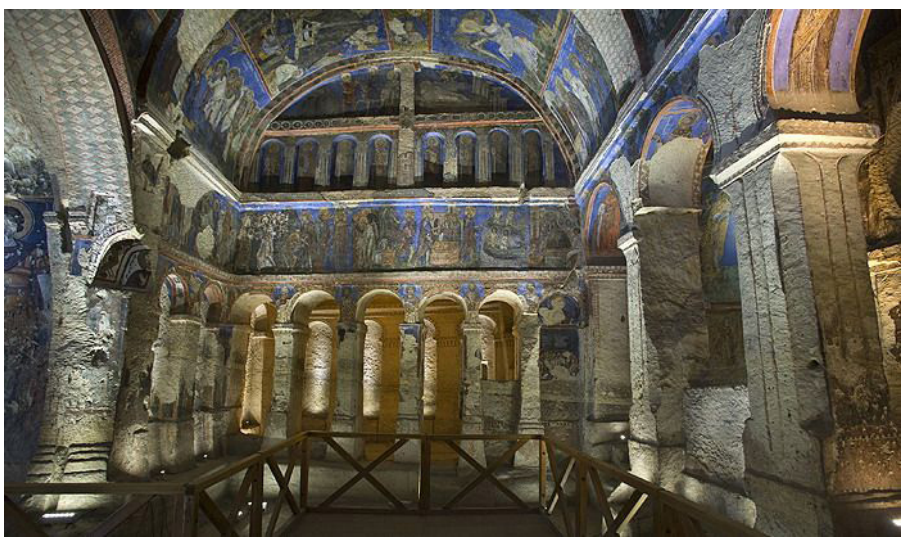

It is known the oldest rock church of the region and it consists of four places: old church with one nave, new church, church under the old church, side chapel in the north of the new church.

The old church dating back to the beginning of the 10th century is the entrance hall of the new church today, but it is originally a single nave, barrel vaulted structure. The apse was completely destroyed during the addition of the new church to the east. The scenes are placed on the vault surface and above the walls. The cycle that covers the life of Jesus is divided into panels in the vault and the scenes start on the right wing and follow the left wing. 


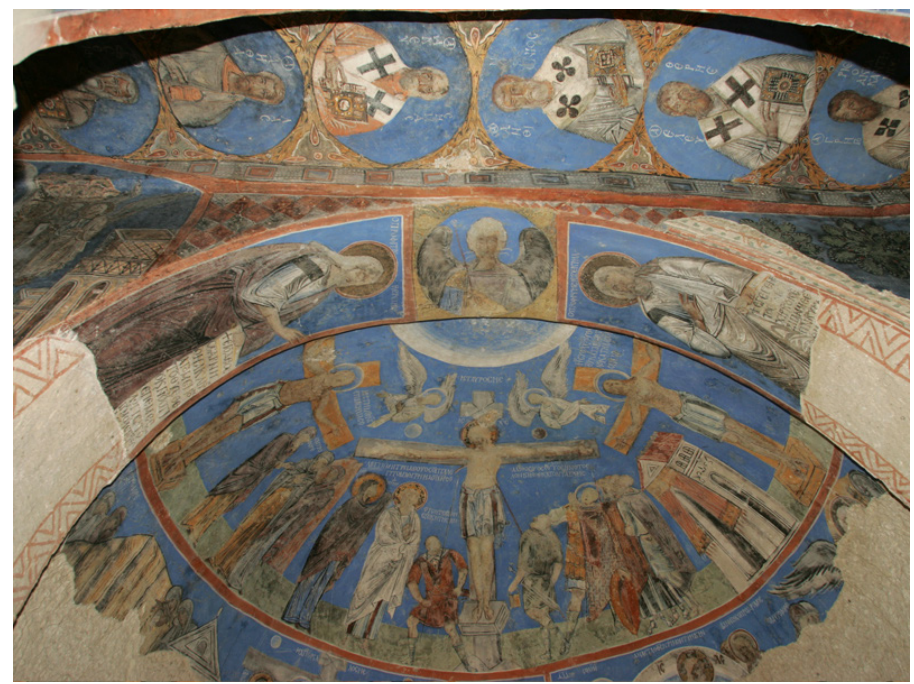

The scenes in the church: depictions of saints in the middle of the vault, the gospel on the upper panel, the visit, the proof of virginity, the journey to Bethlehem, the birth, the worship of three astrologers in the upper panel on the left wing, the massacre of innocent children, the escape to Egypt, the introduction of Jesus in the temple, Zechariah the murder of John, the prophecy of John the Baptist, the prophecies of John the Baptist, the meeting of Jesus with the baptist, John, baptism, bloodthirsty; the miracle of wine in the middle panel in the left wing; the propagation of breads and fish; the appointment of the apostles; the improvement of the blind man; at the bottom panel of the right wing, the entrance to Jerusalem, the last dinner, betrayal, in front of the Jesus platus, in the lower panel on the left wing Jesus on the way to golgota, Jesus on the cross, the crucifixion of Jesus, the burial of Jesus, women at the empty grave of Jesus Christ descent, Jesus' rise to heaven. 
Note: The images used in this article are taken from https://www. kulturportali.gov.tr/.

Хакан Јалап

\section{GOREMЕ - МУЗЕЈ ПОД ОТВОРЕНИМ НЕБОМ}

Goreme Музеј под отвореним небом је један од најзаступљенијих творевина Кападокије. Овај регион је 1985. године проглашен светском баштином од стране Унеска. Музеј на отвореном је око 2 км од самог града Гореме, на јужној страни. Од 4. до 13. века, на овом месту је искусан монашки живот.

У почетним деловима долина у региону Кападокије, велики камени блокови обично су формирани као резултат природне ерозије. Музеј је основан у непосредној близини такве долине и готово сваки камени блок у околини је изрезан и искоришћен у разне сврхе.

Музеј се састоји од манастира, цркава, капела, трпезарија, кухиње и живих простора изрезаних у стену. Манастирски систем образовања покренут је у Goreme Музеју под отвореним небом. Цркве су обојане са 2 врсте техника, коришћењем sесco (темпера) и фреска технике на стени. Теме које су осликане баве се Библијом, пророком, као и деловима из Исусовог живота.

Овај регион је основао св. Василије, епископ Кајсери, важна особа у историји хришћанства. Идеје св. Василија, које су донеле доста иновација у хришћанску мисао, прво су учене овде. Монашки живот трајао је 1000 година.

Кападокија је окружена црквама урезаним у стене свуда, има око 360 уклесаних цркава. Goreme Музеј под отвореним небом садржи најбоље очуване византијске цркве и фреске и представља круну ове регије.

Кључне речи: Goreme Музеј под отвореним небом, Кападокија, Турска, хришћанство. 